\title{
ETHEREAL BEAUTIES AND EMBODIED SEXUALITIES: WOMEN AND THE ARTICULATION OF BRAZILIAN WHITENESS
}

\begin{abstract}
This article deploys an intersectional lens to refract discourses of race, gender, and sexuality and shine light on the lived experience of whiteness of self-identified white women from the middle-classes in Florianópolis in the South of Brazil. It demonstrates how a complex interplay between beauty and (a)sexuality constructs a culturally mediated expression of national belonging which casts white women outside the imagery of Brazilian womanhood, feeding an existential, although not socioeconomic, sense of loss. The alienation felt by the women in question is analytically located in whiteness, but this whiteness seems to evade culpability, preserving its dominance by pushing the women's gender identities to the fore. Through analysis of both historical processes and contemporary lived experiences it isolates 'beauty' as a contextually specific 'revealing construct' which enables us to understand the processes through which whiteness preserves its dominance through the intersection of race, gender, sexuality, and nationhood.
\end{abstract}

Keywords: whiteness, Brazil, beauty, sexuality, gender

\section{Introduction}

As I walked one afternoon down the Avenida das Rendeiras in the east of the Ilha de Santa Catarina, the southern Brazilian island that is home to the city of Florianópolis, I noticed a new billboard about halfway down the street. It advertised a local television programme called Contemporânea: A arte de ser mulher (Contemporary: The art of being a woman) and from it smiled down a fair-haired woman, a gleaming and groomed exemplar of how to 'be' a particular type of woman. Immaculately dressed and made up, clearly middle-class, white teeth gleaming, and supremely confident in her mastery of the art in question, she stood as an archetype of modern urban femininity. 
I decided that I had to ask my friend Luciana for her thoughts, and pointed up at the billboard asking "what do you think of that?" Having been put on the spot she was unsurprisingly a bit confused, and assuming that I meant the programme itself told me she had never heard of it, let alone seen it. Realising that rather than simply pointing and demanding answers I would have to provide some kind of context I asked specifically what she thought about the idea that the woman was a representative of the art of being a woman. Luciana thought for a moment and then replied "well, she is beautiful, her clothes are very stylish, but it couldn't really be 'The art of being a $\mathrm{Bra}$ zilian Woman', you know? Because she doesn't have that kind of sensuality, that sexuality, you know?" And I did know. Even for Luciana, a blonde woman in a very white city in the South of Brazil, it seemed incongruous that a woman who looked like her was being called upon to represent womanhood. Her beauty allowed her to stand as an archetype of a universalised womanhood, but when cast as such within a Brazilian context her gendered nationality was thrown into doubt, somehow lacking the sexuality to truly represent the art of being a Brazilian woman. Her whiteness did not stand in the way of her feminine beauty, but it did her sexuality.

Drawing on a fifteen month period of ethnographic fieldwork in 2008-2009 in the city of Florianópolis in the South of Brazil ${ }^{2}$ I will examine the cultural landscape in which this woman who was in so many ways privileged, confidently staring across the cityscape, could be alienated from national belonging. This dynamic, I will argue, leads many racially privileged white women to feel ambivalent towards their whiteness. Following an intersectional approach the focus will be on the construction of 'beauty', which I argue serves as one of Collins' "sites of intersectionality", ${ }^{3}$ points where intersecting oppressions converge in revelatory ways. Female beauty is a site at which race, gender, and sexuality come together, a "revealing construct" which can illuminate deeper, and seemingly unrelated, cultural structures and relationships ${ }^{4}$ revealing here a white female identity which is never permitted to feel Brazilian.

\section{The beauty of blondes...}

The intersection of race, gender, sexuality and nation most viscerally manifested itself to me within that most (stereotypically) Brazilian of environments, the carna$v a l$. I was with Mônica enjoying the heat and spectacle of the rehearsals held in the

1 All quotes derived from fieldwork are my translations from the original Portuguese. Only my translations from published works will henceforth be marked as such.

2 This fieldwork was funded by a UK ESRC 1+3 Studentship - PTA-030-2006-00356.

3 P.H. Collins, Black Feminist Thought: Knowledge, Consciousness, and the Politics of Empowerment, Routledge Classics, New York-London 2009 [2000], p. 138.

4 See D. Gordon, A beleza abre portas: Beauty and the Racialised Body Among Black Middle-class Women in Salvador, Brazil, "Feminist Theory" 2013, no. 14(2), pp. 203-218. 
barracão $o^{5}$ of one of the samba schools in Florianópolis, and as the band played on the stage and the multitude gleefully danced the scene was stolen by the young women dancing furiously in the centre of tent. Mônica pointed her out to me and told me with a look of scepticism on her face that this blonde young woman was the Rainha da Bateria, the carnaval queen and the public face of the School. She then asked me, in a tone dripping with scorn, "is she our queen? That little blonde girl who doesn't know how to dance? She can't be!" I could not help but agree, as within this most 'Brazilian' of settings a blonde carnaval queen did seem out of place. As another friend, Marcinha, succinctly put it the following week, "the queen has to be either negra or mulata!", and not some "little blonde girl".

The issue was not that she was not considered beautiful enough to be the queen, constructions of female beauty in Brazil are fed by a deep running connection between white, and specifically blonde, women and beauty - white skin operating as what Pinhodescribes as "a cipher of beauty" which runs deeply through Brazilian society. For anyone who goes to Brazil it is inescapable on the streets and in the media that the images of women most used in advertising are those of young white women, ${ }^{7}$ part of a "whitewashing" of the Brazilian subject wherein "white persons and white families are cast as the symbols of beauty, happiness, and middle-class success". ${ }^{8}$ Perhaps the best exemplar of this connection between beauty and whiteness is Xuxa, the blonde former model and star of music and television. Xuxa embodies what I call a "totemic whiteness", a whiteness of great hermeneutic significance which both constructs and reflects the society in which it is located. ${ }^{9}$ Xuxa came to be taken as the personification of beauty within Brazil,${ }^{10}$ and she is therefore a useful medium through which to conceptualise whiteness in Brazil because she functions as a totem for transmitting a particular racialized ideology of white superiority and beauty to the nation.

The whiteness that Xuxa embodies is linked to beauty and success, and these came to be represented in the media as attributes of the blonde, leading to what Ame-

The name given to the rehearsal spaces of samba schools. For an evocative description of the barracão of one of Rio de Janeiro's biggest schools see N. Pravaz, Hybridity Brazilian Style: Samba, Carnival, and the Myth of "Racial Democracy" in Rio de Janeiro, "Identities: Global Studies in Culture and Power" 2008, no. 15 (1), pp. 80-81.

6 P. de Santana Pinho, White but Not Quite: Tones and Overtones of Whiteness in Brazil, "Small Axe" 2009, no. 13 (2), p. 47.

7 I. Beleli, Corpo e identidade na propaganda, "Revista Estudos Feministas" 2007, no. 15 (1), pp. 201-202.

8 E.E. Telles, Race in Another America: The Significance of Skin Colour in Brazil, Princeton University Press, Oxford 2004, p. 155. See also: S.N. Joyce, Brazilian Telenovelas and the Myth of Racial Democracy, Lexington Books, Plymouth 2012.

9 For discussion of this in the context of the USA see: J. Hartigan, Odd Tribes: Toward a Cultural Analysis of White People, Duke University Press, London 2005, p. 199.

10 S. Radcliffe, S. Westwood, Remaking the Nation: Place, Identity and Politics in Latin America, Routledge, London 1996, p. 139. 
lia Simpson describes as the "tyranny of the blonde". ${ }^{11}$ It is an accurate reflection of the place of whiteness and blondeness in the construction of female beauty in Brazil when Peter Wade argues that

[t]he success of the Brazilian model and TV presenter Xuxa shows the striking dominance of whiteness as the norm of female beauty. Xuxa's Aryan blonde looks and her manipulation of her sexual image converted her into a Marilyn Monroe-style sex symbol who, through her pervasive media promotion, both reflected and strongly reinforced the value attached to whiteness. ${ }^{12}$

That the promotion of Xuxa was, and continues to be, a sign of the racist etching of beauty onto blonde hair and white skin within Brazil is clear, but where I disagree however is in Wade's formulation of Xuxa as a sex symbol.

\section{Separating 'sex' and 'beauty'}

The 'tyranny of the blonde' that Simpson describes operates in particular ways, and this does not necessarily mean that being beautiful translates into being a sex symbol. Instead the tethering of blondeness to beauty in Brazil creates a paradox, and just as Wade argues that "blackness in both men and women is often associated with sexual desirability... but the erotically desirable is not always the same as the aesthetically beautiful", ${ }^{13}$ so too, I argue, is the aesthetically beautiful not always the same as the erotically desirable. Alexander Edmonds ${ }^{14}$ explores the construction of a contextually Brazilian beauty by referring to the influential figure of Gilberto Freyre, the Brazilian intellectual who more than any other influenced the development of the Brazilian discourse of Racial Democracy through the twentieth century. Edmonds stresses that in Europe and North America understandings of beauty are heavily influenced by a Kantian aesthetics which values 'disinterested contemplation', leading physical beauty to become distanced from the body, and therefore from sexuality. In Brazil Freyre argued instead for an understanding more influenced by Nietzsche, within which the erotic and the aesthetic are not separated, and indeed are intermingled within the body and understood as "the truest form of beauty". ${ }^{15}$ This allowed Freyre to promote his notion of racial mixture as the true, and beautiful, ex-

11 A. Simpson, Xuxa: The Mega-marketing of Gender, Race and Modernity, Temple University Press, Philadelphia 1993, p. 164.

12 P. Wade, Race and Sex in Latin America, Pluto Press, London 2009, p. 186.

$13 \quad$ Ibidem, p. 184.

14 A. Edmonds, Pretty Modern: Beauty, Sex and Plastic Surgery in Brazil, Duke University Press, London 2010, pp. 130-131.

15 Ibidem, p. 31. See also: J. Dewulf, New Man in the Tropics: The Nietzschean Roots of Gilberto Freyre's Multiracial Identity Concept, "Luso-Brazilian Review” 2014, no. 51 (1), pp. 93-111. 
pression of Brazilian national identity through the idealized body of the mixed-race Brazilian woman, the mulata. ${ }^{16}$

This Brazilian understanding opens beauty up for the racially mixed, whilst simultaneously trapping white women within a disembodied Kantian aesthetic. Although a valued beauty is clearly attached to blondeness, this also leads to it being pushed into a kind of phantasmal sphere of Otherness where blonde beauty is an ideal from another place, a foreign aesthetic import not 'of' Brazil, and therefore untouchable, something only to be gazed upon, beautiful but not sexual. This means that whiteness, for women, is inscribed with beauty, but denied an earthly, physical, sexuality, a privilege which therefore relies on a lack of corporeal engagement within the nation. The price to be paid for the perceived beauty of the branca, and particularly the blonde, is that it makes them something to be admired, not someone who has sex. As Luciana recognised in the billboard image, beauty may be blue-eyed and white, this is not sufficient in Brazil for one to be sexy. ${ }^{17}$ To be sexy it is better to be a mulata, with all of the imagery of voluptuous sexuality and carnaval that this brings with it. I would therefore agree with Natasha Pravaz that "lighter the skin, the greater the social value. To a point, that is", and I argue that the location of this point in the construction of the Brazilian female sexual subject is a crucial, and as yet unexamined, space in the Brazilian racial and gendered firmament". ${ }^{18}$

\section{The Colour of Brazilian Sexuality}

It may appear that being seen as beautiful, rather than being objectified as purely sexual, is the lesser of two evils, but this overlooks the importance of sexuality in the construction of Brazilian gendered subjects. When John Norvell describes Brazil as "a nation literally made in the bed" 19 he is referring to a particular metaphorical bed, the bed of the white Portuguese man, which symbolically became the coital crucible of the Brazilian nation. Within the coercive colonial encounter that occurred race intersects with gender and sexuality through the inscription of race into valuations of sexual desirability. ${ }^{20}$ Gilberto Freyre argued that the negra slave was the woman with whom the white Portuguese man copulated in the original colonial encounter, leading

16 S. Maia, Sedução e identidade nacional: Dançarinas eróticas brasileiras no Queens, Nova York, "Revista Estudos Feministas" 2009, no. 17 (3), pp. 769-797. See also: N. Pravaz, The Tan from Ipanema: Freyre, "morenidade”, and the Cult of the Body in Rio de Janeiro, "Canadian Journal of Latin American and Caribbean Studies” 2009, no. 34 (67), pp. 79-104.

17 S. Maia, op. cit., p. 781.

18 N. Pravaz, The tan from Ipanema..., op. cit., p. 80.

19 J.M. Norvell, A brancura desconfortável das camadas médias brasileiras, in: Y. Maggie, C. Barcellos Rezende (eds.), Raça como retórica: A construção da diferença, Editora Civilização Brasileira, Rio de Janeiro 2002, p. 248 (my translation).

20 D. Goldstein, "Interracial” Sex and Racial Democracy in Brazil: Twin Concepts?, "American Anthropologist” 1999, no. 101 (3), p. 564. 
to the construction of their symbolic offspring, the mulata woman, as the representation of the nation..$^{21}$ The mulata and the white man became the Brazilian archetypes, playing a fundamental role in the creation of the racially-mixed nation that Brazil was constructed as being through the discourse of racial democracy. ${ }^{22}$ In keeping with her colonial roots this mulata sexual subject becomes "defined by sex, by sensuality and by unrestrained desire". ${ }^{23}$

This dehumanising view of black women was constructed within the discourse that enabled racism to develop, fed by the imagery of female slaves as having been the hypersexual and perverse African corrupters of a 'pure' European sexuality, the supposed initiators of sex, rather than victims of sexual violence within the structures of slavery, women whose existence is tied to the satisfaction of white male desire. ${ }^{24}$ Jane-Marie Collins argues that both in the colonial era and in contemporary Brazil the supposed innate hypersexuality of the black woman enabled patriarchal society to view rape as impossible..$^{25}$ The construction of 'the African' as purely sexual, the victim of a brutal Cartesian division between body and mind, was common throughout the European colonial project, ubiquitously resulting in a negative "imagery constructing black women's sexuality as overactive, deviant, excessive, closer to nature, not in control, and animal-like". ${ }^{26}$ It is clear, as Wade ${ }^{27}$ argues, that the valuing of blackness on purely sexual terms is therefore not much of a valuation at all, and evidence of the negatives that accrue to mulatas through this sexualisation is not difficult to find, not least in the objectifying attitudes of white men in Brazil. ${ }^{28}$

There is however a way for those mulatas deemed to approach whiteness in their physical appearance, particularly skin colour and those facial features that are described as traços finos, 'fine features' that are associated with whiteness, to access the whitened ideal of beauty, whilst retaining an 'innate' sexuality. The path through which "[b]lack is made beautiful (..) by the addition of white features" ${ }^{\prime 29}$ was described to me one night by Luisa as she told me about a woman who is beautiful 'despite' being a mulata. She instantly realised that it was necessary to qualify this statement, and added that

21 C. Ferreira-Pinto, Gender, Discourse, and Desire in Twentieth-Century Brazilian Women's Literature, Purdue University Press, West Lafayette 2004, p. 25. See also: C.B. Rezende, M. Lima, Linking Gender, Class and Race in Brazil, "Social Identities" 2004, no. 10 (6), p. 758.

22 S. Maia, op. cit., p. 771.

23 L. Moutinho, Razão, “Cor” e Desejo, Fundação Editora da UNESP, São Paulo 2004, p. 345 (my translation).

${ }^{24}$ Ibidem, p. 246. See also: C.B. Rezende, M. Lima, op. cit., p. 760.

25 J.-M. Collins, Intimacy, Inequality and "Democracia Racial": Theorizing Race, Gender and Sex in the History of Brazilian Race Relations, "Journal of Romance Studies" 2007, no. 7 (2), p. 27-28.

26 G. Wekker, The Politics of Passion: Women's Sexual Culture in the Afro-Surinamese Diaspora, Colombia University Press, New York 2006, p. 226.

27 P. Wade, op. cit., p. 189.

28 E.E. Telles, op. cit., p. 191.

29 D. Goldstein, op. cit., p. 571. 
(...) she is tall and pretty, really beautiful, and she would be beautiful anywhere, you know?

(...) Everyone thinks she's beautiful. It's because the girl has a really beautiful face, you know? With features, you know, more like, like, ours. And she is sexy, she's got that incredible voluptuous mulata's body! $!^{30}$

As she said this touched her own face with her left hand, and pointed to mine with her right hand, making it perfectly clear that the features she was referring to were those of white people, the 'fine' features that are fundamental to aesthetic (Kantian) understandings of beauty. It is due to these 'white' features that the woman could be considered beautiful, because this standard of beauty is constructed as universal, and linked to whiteness. This clearly shows that whilst she would likely be considered sexy due to being a mulata, she is 'privileged' to have a face that can also be read as white, and is therefore beautiful in both senses, a rare combination given that a mulata must not only conform to white beauty standards, but exceed them. ${ }^{31}$

\section{The desexualised branca from the historical to the contemporary}

Not only can the representation of the mulata as highly sexualised and sexually attractive be traced to colonial times, but this was also an era in which women of all races had their sexualities and gender roles constructed in relation to white men. ${ }^{32}$ It is here that we see the roots of the construction of white women, however beautiful they may be considered, as desexualised..$^{33}$ Moutinho argues that the protection of the chastity and virtue of the white woman in colonial Brazil led to the sexualisation of negras and mulatas, who were sexually 'available' to white men as the pay-off for these men to accept that white women were sexually unavailable to them outside wedlock. ${ }^{34}$ White girls were then to be preserved as simple, delicate flowers 'protected' from of their own sexuality as

(...) [d]uring the day the white girl or young woman was subject to the gaze of her elders or of the trusted black maid. At night the vigilance grew. Sleep became a spontaneous prison, in the bedroom, at the centre of the house, under the guard of the adults..$^{35}$

30 Ibidem.

31 L. Moutinho, op. cit., p. 309.

32 P. Wade, op. cit., p. 57.

33 R. Dyer, White, Routledge, London 1997, p. 130.

34 L. Moutinho, op. cit., p. 93. Most European colonial powers believed it necessary to protect the chastity and purity of white women in the face of the possible corruptions of the tropics, whilst simultaneously constructing the non-white Other as sexual. T. Mayer, Gender Ironies of Nationalism: Setting the Stage, in: T. Mayer (ed.), Gender Ironies of Nationalism: Sexing the Nation, Routledge, London 2000, p. 10.

35 F. Quintas, Sexo à moda patriarchal: O feminino e o masculino na obra de Gilberto Freyre, Global Editora, São Paulo 2007, p. 51 (my translation). 
The virginity of the girl needed to remain intact in order that she be 'suitable' for marriage when she became a woman. This marriage then marked the start of the second role she was expected to fulfil, that of the dutiful wife. ${ }^{36}$

The colonial era saw the birth of the discourse of racial mixture, mestiçagem, and "in this narrative «white» women occupy the almost asexual role of the loyal wife". ${ }^{37}$ She was 'almost asexual' because she did still have a sexual role to fulfil, that of reproduction, but her pleasure was not a factor, this was sex on the white man's terms, and wives were still closely watched. ${ }^{38}$ It was through this process that the

(...) erotic desire of the "colour white" appears only in the masculine pole, which is completed by the lubrication of the "mulata." The "white" woman appears always de-eroticised in this relationship. ${ }^{39}$

The white man, the branco, is the only real sexual subject in this formulation, because the "realisation of desire, constituted and controlled by the colonial (and also national) machine, constituted itself on the path that articulated the white man". ${ }^{40}$ Sex was something that happened between white men and mulatas, whilst what happened between white men and white women was simply reproduction. All that mattered was the sexual gratification of the white man, and the mulata and the branca fulfilled different sexual roles in this service. ${ }^{41}$

This imagery of the hypersexual mulata is both ahistorical and not reflective of contemporary experience because it does not carry over seamlessly into the ontological world. She is clearly a hypersexual representation constructed by the white male imagination, and in this sense I link her Xuxa. Just as Xuxa acts as a decorporealised totem for notions of aesthetic beauty, so too do the discursively rendered mulata and her ontological offspring, mulatas in contemporary Brazil, act as symbols of Brazilian female hypersexual corporeal beauty. This construction has survived from slavery through to the imagery of carnaval constructed in the first half of the twentieth century, when "Carnaval and the image of the mulata, as symbols of a miscegenised and sexualised nation, became symbols of the festive essence of the Brazilian". ${ }^{42}$ This is why the archetypal brasileira remains cast in the image of the mulata, the symbol of the nation and the carrier of Brazilian notions of female sexuality and male sexual

36 It was also to 'protect' her from black men, who were present within this colonial scenario only as a threat to the white man's sexual dominion over women, written out, yet always present as a source of white anxiety.

37 P. Fry, Preface, in: L. Moutinho, op. cit., p. 13 (my translation).

38 F. Quintas, op. cit., p. 52.

39 L. Moutinho, op. cit., p. 169.

$40 \quad$ Ibidem, p. 423.

41 This was not unique to Brazil, as Katerina Deliovsky stresses when she writes that "feminine beauty has less to do with physical perfection (although there is a physical component) and more to do with behaviour and decorum in the service of "white' masculinity". K. Deliovsky, White Femininity: Race, Gender and Power, Fernwood Publishing, Halifax-Winnipeg 2010, p. 118.

42 S. Maia, op. cit., p. 772 (my translation). 
pleasure. ${ }^{43}$ The mulata becomes the symbolic construction of the brasileira and the branca is cast as a foreign presence within the nation. This is why the blonde queen of the samba school seemed out of place and inauthentic.

\section{An alien whiteness in a miscegenised nation}

It is beyond question that the view of Brazil as a tropical country of carnaval, mulatas, and palm trees, is an imagined Brazil, and it is also clear that it is based particularly on the imagery of Rio de Janeiro, and to a lesser degree the state of Bahia. This imagery is very obviously racialized, gendered and sexualised, and white Brazilian women are abundantly aware of the fact. I frequently heard from Southern Brazilians such as Bruna, herself born and raised in Florianópolis, that when they think of the typical brasileira it is the image of the woman from Bahia, the $b a$ iana, or the woman from Rio de Janeiro, the carioca, that comes to mind. The carioca in the form of the samba-dancing mulata with her voluptuous body and gyrating hips is the most powerful image of Brazil according to Bruna, and this is not just an imagery imposed from abroad, because as Fabiana was only too ready to point out "we are responsible for this as well (...) not only because the government sells [advertises] the country like this, it is also the image of how a brasileira must be, sort of the true brasileiras". This racialized and sexualised image of the brasileira mulata occupies such a powerful position in the Brazilian imaginary and discourse that she becomes the true, the authentic, and, after a fashion, the only Brazilian woman, and her sexuality is at the centre of this construction. ${ }^{44}$

This places the branca beyond authenticity, and denies her this Brazilian sexuality, feeding the perception that she is imported, that whiteness and blondeness are not 'of' Brazil. Luisa is from the city of Campinas in São Paulo state, and is a lover of samba de rais, the traditional style of samba, the best of which tends to be found in the poorer, and therefore often negro, neighbourhoods of Brazil's cities. She goes because she loves the music, but often feels that she is being stared at, as though she is out-of-place, and this makes her uncomfortable. She told me that Deise, the negra cleaner at her parent's house, could not understand why Luisa had a problem with being stared at. Deise felt that being the centre of attention must be a good thing and Luisa should have felt special. Luisa told me that she therefore felt guilty about complaining about being visible to a negra cleaner who spent most of her life being ignored, but despite knowing it was largely due to her position of privilege it still discomforted her to be seen as different. This was a discomfort she had felt since she was a child, when the other children had called her hair vermelho, literally red, rather than ruivo, the Portuguese word specifically for red hair. They did not do this to bully her, she assured me, but rather because as she was the only ruiva (red-haired

43 Ibidem. See also: N. Pravaz, op. cit., p. 84, and E.E. Telles, op. cit., p. 190.

44 S. Maia, op. cit., p. 774. 
woman) they had ever met they simply did not know the word. She was so different that people did not know the correct terminology to describe her, and in a sense this made her feel that within Brazil she did not exist. Her body placed her outside Brazil, and no amount of beauty could bring her inside, and indeed any attention that Luisa received only reminded her of the foreignness of her body within her own country.

White women can attempt to counteract this by engaging in social practices informed by a desire for what Hage describes as a particular cultural capital that is tied to the nation, and whose effect is that

(...) national belonging tends to be proportional to accumulated national capital. That is, there is a tendency for a national subject to be perceived as just as much as a national as the amount of national capital he or she has accumulated..$^{45}$

Women's common reaction when their whiteness seems to cast them outside of Brazil, when they cannot reconcile their self-identified whiteness with their Brazilianness, is to deny their whiteness. ${ }^{46}$ This was a sentiment I also heard expressed many times, for example by Francesca, who when I asked her about her race replied "I'm not (...) racially mixed, so I don't exist". As a fair-haired woman who did not want to describe herself as being white, as being anything other than brasileira, she encountered difficulties, as to be brasileira links so closely to racial mixture. This helps explain why people whose racial position in a society is hyper-privileged often feel hesitant to claim whiteness, as within the discourse that constructs the Brazilian, and particularly the Brazilian woman, this "rejection of whiteness, albeit on a rhetorical level, is (...) a means of affirming one's belonging to the nation and an expression of the belief that being «too white» challenges one's Brazilianness". ${ }^{47}$

To deny to oneself a racial identification that confers power and dominance becomes understandable only within the discourse founded within Racial Democracy. White Brazilian men can make their claim to membership of the nation from the position of the active Portuguese colonist, as within the sexual imagery of Brazil the male sexual subject is white. As Isfahani-Hammond demonstrates through the example of the white male writers who contributed to the development of the idea of Brazil as a Racial Democracy it has always been open for white men to claim Brazilianness for themselves, and even to speak for the Afro-Brazilian population through

45 G. Hage, White Nation: Fantasies of White Supremacy in a Multicultural Society, Routledge, New York 2000, p. 53.

46 S. Maia, op. cit., p. 775.

47 P. de Santana Pinho, op. cit., p. 46. Rosa-Ribeiro argues that even when white Brazilians remain white to the gaze of others they do not really lose power, and whilst I would agree broadly that their racial power is retained, I would argue that women particularly may experience the sensation of loss which comes with being viewed as less than wholly Brazilian. F. Rosa-Ribeiro, Racism, Mimesis and Anthropology in Brazil, "Critique of Anthropology" 2000, no. 20 (3), pp. 221-241. 
the deployment of what she terms "white negritude". ${ }^{48}$ White women, on the other hand, have only the image of the mulata to call upon, as the Portuguese woman never appears in the story, other than, perhaps, hidden behind a sheet with a hole cut in it. Within a nation where sexuality forms such an important part of the construction of national identity ${ }^{49}$ this was seen by all of the white women with whom I spoke to be undesirable, that sheet would separate them not only from the physical act of sex but also from the nation itself.

\section{Conclusion}

I have argued here that both historically and in contemporary Brazil the 'authentic' Brazilian female sexual subject is a sexualised mulata. White, and particularly blonde, brasileiras are instead granted a beauty, and a highly valued beauty at that, and this should be neither overlooked nor underplayed. The problem for white women however is that this beauty is read through a Kantian aesthetic lens, it is 'foreign' and seems to float above Brazil, as the billboard floats above the street, never managing to touch its feet on Brazilian soil. For them an authentically Brazilian beauty continues to be tied to the discourse of Racial Democracy, to Freyre's ideas of the embodied beauty of miscegenation. This then results in the sexualised beauty embodied by the discursively rendered mulata having a place, albeit a heavily objectified place, within Brazil, whilst the white Brazilian woman can feel herself disconnected from the imagery of Brazil, and separated from Brazilian identity and nationhood.

At first glance this might appear to serve as a check on the power of whiteness in Brazil, that white women's sense of estrangement from the nation by virtue of their whiteness might offer opportunities for the challenging of white dominance. I argue however that it actually serves to demonstrate how entrenched and elusive white dominance is. The women did not express discomfort with whiteness itself, and very few made attempts to challenge or reject the privilege their whiteness endows upon them. What discomfort they felt was based on the sense that their whiteness distanced them from Brazilian womanhood. This could legitimately be read as the selfish preoccupation of the spoilt middle-classes, and of little consequence beyond their own privileged lives, but I believe however that we should view this as a demonstration of the workings of whiteness, the ways in which it mobilizes and protects its power and dominance. This power and dominance is articulated within, and dependent upon, the very specific context in which it operates. Whiteness in Brazil was constructed within a colonial history, an entrenchment through Racial Democracy, and a continuing elaboration through the twentieth century and into the twenty-first cen-

48 A. Isfahani-Hammond, White Negritude: Race, Writing, and Brazilian Cultural Identity, Palgrave Macmillan, Basingstoke 2008.

49 R.G. Parker, Bodies, Pleasures and Passions: Sexual Culture in Contemporary Brazil, Beacon Press, Boston 1991, pp. 7-8. 
tury, and this has given it a contextual grammar within which gender and sexuality are of the greatest importance within the intersectional lived experience of whiteness for women. The women described their whiteness through their gender and sexuality, not through racial politics.

Beauty, through its place within the Brazilian imagination, therefore exerts a powerful pull which largely overwhelms considerations of racial politics. This should not however lead to the conclusion that white Brazilian women are somehow less cognisant of, or morally opposed to, white racial hegemony. I argue instead that it is the result of the power dynamics which whiteness relies upon to preserve its dominance in Brazil. The historical and patriarchal base of this drives women to worry less about race than about the specific influence of race on gender and sexuality, leaving racial power less challenged and interrogated than it may be in other contexts. Without understanding how these kinds of articulations function in different contexts there is less possibility of a challenge to the preservation of white racial hegemony. Recognizing that race, gender and sexuality are all involved in the articulation of whiteness is one thing, but it is crucial also to understand that their weighting is the key to dissecting how they articulate together to construct gendered whitenesses.

In order to understand and challenge whiteness we must find contextually appropriate concepts and constructions which offer insights in this respect. The practice of anthropology is well placed to deepen our insights into the lived experience of race, gender and sexuality and can help us point towards the 'revealing constructs' which might offer the clearest views of the 'dense transfer points for relations of power' where the workings of such ideologies as whiteness become most visible. I have demonstrated here that beauty in Brazil, as understood through white women's lived experience of race and gender, is just such a 'revealing construct' which enables us to understand the ways in which an evasive and elusive whiteness retains power through deflecting critique towards concerns of gender and sexuality.

\section{References}

Beleli I., Corpo e identidade na propaganda, "Revista Estudos Feministas" 2007, no. 15 (1), pp. 193-215.

Collins J.-M., Intimacy, Inequality and "Democracia” Racial: Theorizing Race, Gender and Sex in the History of Brazilian Race Relations, "Journal of Romance Studies" 2007, no. 7 (2), pp. 19-34.

Collins P.H., Black Feminist Thought: Knowledge, Consciousness, and the Politics of Empowerment, Routledge Classics, New York-London 2009 [2000].

Deliovsky K., White Femininity: Race, Gender and Power, Fernwood Publishing, HalifaxWinnipeg 2010.

Dewulf J., New Man in the Tropics: The Nietzschean Roots of Gilberto Freyre's Multiracial Identity Concept, "Luso-Brazilian Review" 2014, no. 51 (1), pp. 93-111.

Dyer R., White, Routledge, London 1997. 
Edmonds A., Pretty Modern: Beauty, Sex and Plastic Surgery in Brazil, Duke University Press, London 2010.

Ferreira-Pinto C., Gender, Discourse, and Desire in Twentieth-Century Brazilian Women's Literature, Purdue University Press, West Lafayette 2004.

Fry P., Preface, in: L. Moutinho, Razão, “Cor” e Desejo, Fundação Editora da UNESP, São Paulo 2004, pp. 13-17.

Goldstein D., "Interracial” Sex and Racial Democracy in Brazil: Twin Concepts?, "American Anthropologist" 1999, no. 101 (3), pp. 563-578.

Gordon D., A beleza abre portas: Beauty and the Racialised Body among Black Middle-class women in Salvador, Brazil, "Feminist Theory" 2013, no. 14 (2), pp. 203-218.

Hage G., White Nation: Fantasies of White Supremacy in a Multicultural Society, Routledge, New York 2000.

Hartigan J., Odd Tribes: Toward a Cultural Analysis of White People, Duke University Press, London 2005.

Isfahani-Hammond A., White Negritude: Race, Writing, and Brazilian Cultural Identity, Palgrave Macmillan, Basingstoke 2008.

Joyce S.N., Brazilian Telenovelas and the Myth of Racial Democracy, Lexington Books, Plymouth 2012.

Maia S., Sedução e identidade nacional: Dançarinas eróticas brasileiras no Queens, Nova York, "Revista Estudos Feministas" 2009, no. 17 (3), pp. 769-797.

Mayer T., Gender Ironies of Nationalism: Setting the Stage, in: T. Mayer (ed.), Gender Ironies of Nationalism: Sexing the Nation, Routledge, London 2000, pp. 1-22.

Moutinho L., Razão, “Cor” e Desejo, Fundação Editora da UNESP, São Paulo 2004.

Norvell J.M., A brancura desconfortável das camadas médias brasileiras, in: Y. Maggie, C. Barcellos Rezende (eds.), Raça como retórica: A construção da diferença, Editora Civilização Brasileira, Rio de Janeiro 2002, pp. 245-267.

Parker R.G., Bodies, Pleasures and Passions: Sexual Culture in Contemporary Brazil, Beacon Press, Boston 1991.

Pravaz N., Hybridity Brazilian Style: Samba, Carnival, and the Myth of "Racial Democracy" in Rio de Janeiro, "Identities: Global Studies in Culture and Power" 2008, no. 15 (1), pp. 80-102.

Pravaz N., The Tan from Ipanema: Freyre, "morenidade”, and the Cult of the Body in Rio de Janeiro, "Canadian Journal of Latin American and Caribbean Studies" 2009, no. 34 (67), pp. 79-104.

Quintas F., Sexo à moda patriarchal: O feminino e o masculino na obra de Gilberto Freyre, Global Editora, São Paulo 2007.

Radcliffe S., Westwood S., Remaking the Nation: Place, Identity and Politics in Latin America, Routledge, London 1996.

Rezende C.B., Lima M., Linking Gender, Class and Race in Brazil, "Social Identities" 2004, no. 10 (6), pp. 757-773.

Rosa-Ribeiro F., Racism, Mimesis and Anthropology in Brazil, "Critique of Anthropology" 2000, no. 20 (3), pp. 221-241.

Santana Pinho de P., White but Not Quite: Tones and Overtones of Whiteness in Brazil, "Small Axe" 2009, no. 13 (2), pp. 39-56.

Simpson A., Xuxa: The Mega-marketing of Gender, Race and Modernity, Temple University Press, Philadelphia 1993. 
Jimmy Turner

Sovik L., We Are Family: Whiteness in the Brazilian media, "Journal of Latin American Cultural Studies" 2004, no. 13 (3), pp. 315-325.

Telles E.E., Race in Another America: The Significance of Skin Colour in Brazil, Princeton University Press, Oxford 2004.

Wade P., Race and Sex in Latin America, Pluto Press, London 2009.

Wekker G., The Politics of Passion: Women's Sexual Culture in the Afro-Surinamese Diaspora, Colombia University Press, New York 2006. 